\section{Increases in Bermudagrass [Cynodon dactylon (L.) Pers.] Tissue Pigments during Post-application Recovery from Mesotrione}

\author{
Dean A. Kopsell ${ }^{1,3}$, James T. Brosnan ${ }^{2}$, and Gregory R. Armel ${ }^{2}$ \\ Plant Sciences Department, The University of Tennessee, 252 Ellington Plant \\ Sciences, 2431 Joe Johnson Drive, Knoxville, TN 37996-4561
}

\author{
J. Scott McElroy ${ }^{1}$ \\ Department of Agronomy and Soils, Auburn University, Auburn, AL 36849
}

Additional index words. $\beta$-carotene, chlorophyll, lutein, phyotene, turfgrass, violaxanthin, zeaxanthin

\begin{abstract}
Mesotrione \{2-[4-(methylsulfonyl)-2-nitrobensoyl]-1,3-cyclohexanedione\} is a herbicide that indirectly inhibits phytoene desaturase in plant tissues, the first step in the carotenoid biosynthesis pathway. The predominant symptom of mesotrione activity is tissue whitening with subsequent plant necrosis. In the current study, 'Riviera' bermudagrass [Cynodon dactylon (L.) Pers.] was treated with mesotrione at $0.28 \mathrm{~kg} \cdot \mathrm{ha}^{-1}$ or untreated and sampled for tissue pigment concentrations at $0,3,7,14,21,28$, and 35 days after treatment (DAT). Visual tissue whitening in mesotrione-treated plants reached a maximum of $38 \%$ by 14 DAT; however, regreening of discolored tissue was observed by 21 DAT. Phytoene was only detected in mesotrione-treated plants at 3, 7, and 14 DAT. Pigments in treated plants decreased with initial tissue whitening; however, most recovered to untreated levels by 21 DAT. At 35 DAT, chlorophyll $a$, chlorophyll $b$, lutein, $\beta$-carotene, and zeaxanthin in mesotrione-treated plants had accumulated to levels exceeding untreated control plants. Results demonstrate that although mesotrione initially decreases bermudagrass pigment concentrations, treatment with this herbicide eventually results in higher concentrations of chlorophylls and carotenoids.
\end{abstract}

The predominant symptom of the herbicide mesotrione \{2-[4-(methylsulfonyl)-2nitrobensoyl]-1,3-cyclohexanedione $\}$ is tissue whitening with subsequent plant necrosis (Mitchell et al., 2001; Pallett et al., 1998; Secor, 1994). Mesotrione directly inhibits the enzyme $p$-hydroxyphenylpyruvate dioxygenase (HPPD; EC 1.13.11.27), a precursor to plastoquinone and tocopherols. The enzyme phytoene desaturase requires plastoquinone as a cofactor for converting phytoene to $\zeta$-carotene, which represents the first step in the carotenoid synthesis pathway. Therefore, mesotrione is an indirect inhibitor of phytoene desaturase because plastoquinone serves as a cofactor for this enzyme. Tissue whitening after mesotrione applications can be attributed to a decrease in chlorophyll and carotenoid production caused by the inactivity of phytoene desaturase. The

\footnotetext{
Received for publication 18 June 2010. Accepted for publication 27 July 2010.

This work was funded through the Tennessee Agricultural Experiment Station.

Mention of trade names or commercial products in this publication is solely for the purpose of providing specific information and does not imply recommendation or endorsement by the University of Tennessee Institute of Agriculture or Auburn University.

${ }^{1}$ Associate Professor.

${ }^{2}$ Assistant Professor.

${ }^{3}$ To whom reprint requests should be addressed; e-maildkopsell@utk.edu.
}

Research is currently underway to determine the efficacy of mesotrione for broadleaf and grassy weed control in managed turfgrass systems. Mesotrione is not currently labeled for use on actively growing bermudagrass [Cynodon dactylon (L.) Pers.] turf. However, injury after application is not excessive enough to induce mortality to bermudagrass plants (Anonymous, 2008; McCurdy et al., 2008a). McCurdy et al. (2008b) demonstrated mesotrione applications reduced leaf blade concentrations of antheraxanthin, $\beta$-carotene, epoxy-lutein, phytoene, violaxanthin, and zeaxanthin up to $21 \mathrm{~d}$ after treatment (DAT) in perennial ryegrass (Lolium perenne L). Therefore, the current study was conducted to determine leaf tissue pigment responses to mesotrione application in bermudagrass turf.

\section{Materials and Methods}

Bermudagrass plant culture. Cores $(10 \mathrm{~cm}$ diameter, $20 \mathrm{~cm}$ depth) of 'Riviera' bermudagrass were collected on 1 Sept. 2005 from the East Tennessee Research and Education Center (Knoxville, TN). Plugs were transplanted into $15-\mathrm{cm}$ diameter pots filled with Sequatichie loam soil (fine-loamy, siliceous, semiactive, thermic Humic Hapludult), $\mathrm{pH}$ 6.1, and $2.1 \%$ organic matter and maintained in a glasshouse in Knoxville, TN (lat. 35.98 N). Plants were allowed to establish for 3 weeks before treatment initiation. Plants were cultured under natural photoperiods and daytime high temperatures for the glasshouse averaged $29.5^{\circ} \mathrm{C}$. Plants were fertilized biweekly with a complete $20 \mathrm{~N}-9.2 \mathrm{P}-16.6 \mathrm{~K}$ fertilizer (Howard Johnson's Triple Twenty Plus Minors, Milwaukee, WI) at a nitrogen rate of $5.2 \mathrm{~kg} \cdot \mathrm{ha}^{-1}$ and watered daily with overhead irrigation to maintain adequate soil moisture. Plants were clipped with hand shears three times per week to a 2-cm height to reflect fairway height. The second replication of the study used plugs from the first collection and was conducted starting 15 Oct. 2005.

Mesotrione treatment. To initiate the study, plants were treated with mesotrione at $0.28 \mathrm{~kg}$ a.i./ha plus non-ionic surfactant (NIS; X-77 Spreader; Loveland Industries, Greeley, CO) on 22 Sept. 2005. Treatments were applied using a $\mathrm{CO}_{2}$-powered backpack boom sprayer containing four flat-fan nozzles (TeeJet 8002 nozzle; Spraying Systems Co., Roswell, GA) calibrated to deliver $280 \mathrm{~L} \cdot \mathrm{ha}^{-1}$ of volume. Before initiation, plants were clipped for the last time, and leaf material was harvested above $2 \mathrm{~cm}$ from individual plants $0,3,7,14,21,28$, and 35 DAT. Both treated and untreated plants were harvested at these intervals.

Bermudagrass visual injury assessment and carotenoid determination. Bermudagrass leaf blade percent visual tissue whitening was assessed at each sampling date before harvest. At harvest, clippings were immediately frozen in liquid nitrogen $(\mathrm{N})$ and placed on ice for transfer to storage at $-80^{\circ} \mathrm{C}$. Tissue pigments were extracted and quantified according to previously published methods (Emenhiser et al., 1996; Kopsell et al., 2007). All clippings 
were first homogenized in liquid $\mathrm{N}$ using a mortar and pestle. $\mathrm{A} \approx 0.50$-g subsample was placed into a Potter-Elvehjem tissue grinder tube (Kontes, Vineland, NJ) with $0.8 \mathrm{~mL}$ of ethyl- $\beta$-apo- $8^{\prime}$-carotenoate (Sigma Chemical Co., St. Louis, MO) as an external standard and $2.5 \mathrm{~mL}$ of tetrahydrofuran (THF). The sample was vortexed and homogenized in the tube using $\approx 25$ insertions with a Potter-Elvehjem tissue grinder pestle attached to a drill press set at $540 \mathrm{rpm}$ while the tube was immersed in ice to dissipate heat. The tube was then placed into a centrifuge for $3 \mathrm{~min}$ at $500 \mathrm{gn}$. Precautions were taken to keep the tissue samples on ice during extraction to decrease degradation and increase percent recovery (Kimura and Rodriguez-Amaya, 1999). The supernatant was removed with a Pasteur pipette, placed into a conical $15-\mathrm{mL}$ test tube, capped, and held on ice during the remainder of the extraction. The sample pellet was resuspended in $2 \mathrm{~mL}$ THF and the extraction procedure repeated. By the fifth extraction, the supernatant was colorless and one additional extraction was conducted. The remaining sample pellet was discarded and the combined supernatants were reduced to $0.5 \mathrm{~mL}$ under $\mathrm{N}$ stream $(\mathrm{N}$-EVAP 111; Organomation Inc., Berlin, MA). Each sample was brought up to a $5.0-\mathrm{mL}$ volume with methanol $(\mathrm{MeOH})$ and vortexed. Samples were then filtered through a $0.2-\mu \mathrm{m}$ polytetrafluoroethylene filter (Econofilter PTFE 25/20; Agilent Technologies, Wilmington, DE) before high-performance liquid chromatography (HPLC) analysis.

Pigment separation and quantification was carried out using an Agilent 1100 series HPLC unit with a photodiode array detector (Agilent Technologies, Palo Alto, CA). The column used was a $250 \times 4.6 \mathrm{~mm}$ i.d., $5-\mu \mathrm{m}$ analytical scale polymeric $\mathrm{RP}-\mathrm{C}_{30}$ with a $10-\times 4.0 \mathrm{~mm}$ i.d. guard cartridge and holder (ProntoSIL; MAC-MOD Analytical Inc., Chadds Ford, PA), which allowed for effective separation of chemically similar carotenoid compounds. The column was maintained at $30{ }^{\circ} \mathrm{C}$ using a thermostatted column compartment. All separations were achieved isocratically using a binary mobile phase of $11 \%$ methyl tert-butyl ether, $88.99 \% \mathrm{MeOH}$, and $0.01 \%$ triethylamine $(\mathrm{v} / \mathrm{v} / \mathrm{v})$. The flow rate was $1.0 \mathrm{~mL} \cdot \mathrm{min}^{-1}$ with a run time of $53 \mathrm{~min}$ followed by a 2-min equilibration before the next injection. Eluted compounds from a $10-\mu \mathrm{L}$ injection loop were detected at $290 \mathrm{~nm}$ (phytoene), $453 \mathrm{~nm}$ [carotenoids, chlorophyll $b(\mathrm{Chl} b)$, internal standard], and $652 \mathrm{~nm}$ [chlorophyll $a(\mathrm{Chl} a)$ ] and data were collected, recorded, and integrated using ChemStation software (Agilent Technologies). Carotenoids evaluated included: $\beta$-carotene, lutein, violaxanthin, and zeaxanthin. These carotenoids were selected based on their active roles in photoprotection and light-harvesting (Demmig-Adams et al., 1996; Frank and Cogdell, 1996). Peak assignments were performed by comparing retention times with internal standards and line spectra (200 to $700 \mathrm{~nm}$ ) obtained from photodiode array detection with authentic standards (CaroteNature, Lupsingen, Switzerland). Recovery rates of ethyl- $8^{\prime}$-apo- $\beta$-caroten- $8^{\prime}$-oate were above $80 \%$, and values were used to estimate carotenoid losses during extraction. Pigments are expressed as $\mathrm{mg} / 100 \mathrm{~g}$ fresh weight (FW) of bermudagrass leaf blade tissue.

Statistical analysis. The experimental design was completely random with two treatments, mesotrione-treated and untreated. Within each treatment, harvest intervals $(0$ to 35 DAT) were treated as subsamples. The experiment was conducted twice with three replicates. All data were subjected to analysis of variance $(P=0.05$; Statistical Analysis Software, Inc., Cary, NC). Treatments were analyzed as main effects, and data were plotted over harvest interval with SD bars presented as a means of statistical comparison.

\section{Results and Discussion}

Mesotrione is an indirect inhibitor of the enzyme phytoene desaturase, which results in tissue whitening with subsequent plant necrosis (Mitchell et al., 2001; Pallett et al., 1998; Secor, 1994). As a result of mesotrioneinduced phytoene desaturase inhibition, an increase in phytoene concentration was observed in mesotrione-treated plants (Fig. 1). Phytoene concentrations were $6.0,2.8$, and $3.2 \mathrm{mg} / 100 \mathrm{~g} \mathrm{FW}$ at 3,7 , and $14 \mathrm{DAT}$, respectively. Phytoene was not quantifiable in treated plants at 21,28 , or 35 DAT nor was it found at any harvest date in untreated plants. Visual bermudagrass tissue whitening was observed in treated plants beginning 3 DAT and continuing until 14 DAT, reaching a maximum of $38 \%$ of the tissue affected. Regreening of discolored tissue was observed by 21 DAT (Fig. 1). No tissue necrosis was observed at anytime in mesotrione-treated bermudagrass. No visual tissue whitening occurred in untreated plants at any harvest date. These results are consistent with previous reports of turfgrass response to mesotrione (McCurdy et al., 2008a, 2008b; Willis et al., 2007).

The observed tissue whitening in treated plants was most likely the result of an in vivo decrease in Chl $a$ and $\mathrm{Chl} b$ (Fig. 2) and individual carotenoids (Fig. 3). Chlorophyll $a$ decreased rapidly from 264.5 to $185.8 \mathrm{mg} / 100 \mathrm{~g}$ FW by 3 DAT for treated plants. Decreases continued until 14 DAT with Chl $a$ concentrations declining to $135.2 \mathrm{mg} / 100 \mathrm{~g} \mathrm{FW}$ in mesotrione-treated plants. Chlorophyll $a$ levels in treated plants increased to untreated plant levels by 21 DAT. By 35 DAT, Chl $a$ concentrations in treated plants increased to $395.8 \mathrm{mg} / 100 \mathrm{~g} \mathrm{FW}$, whereas Chl $a$ concentrations in untreated plants were only 166.5 $\mathrm{mg} / 100 \mathrm{~g} \mathrm{FW}$ (Fig. 2). Chlorophyll $b$ also decreased after mesotrione treatment; however, the decrease was not as rapid as Chl $a$. Chlorophyll $b$ did not differ between treated and untreated plants until 7 DAT. Similar to Chl $a$, Chl $b$ concentrations in mesotrionetreated plants continued to decrease until 14 DAT and did not differ from untreated plants by 21 DAT. By 35 DAT, Chl $b$ concentrations in treated plants increased to $105.5 \mathrm{mg} / 100 \mathrm{~g}$ $\mathrm{FW}$, whereas $\mathrm{Chl} b$ concentrations in untreated plants were only $50.0 \mathrm{mg} / 100 \mathrm{~g} \mathrm{FW}$ (Fig. 2).

Within the thylakoid membranes of chlorophyll organelles, carotenoids are bound to

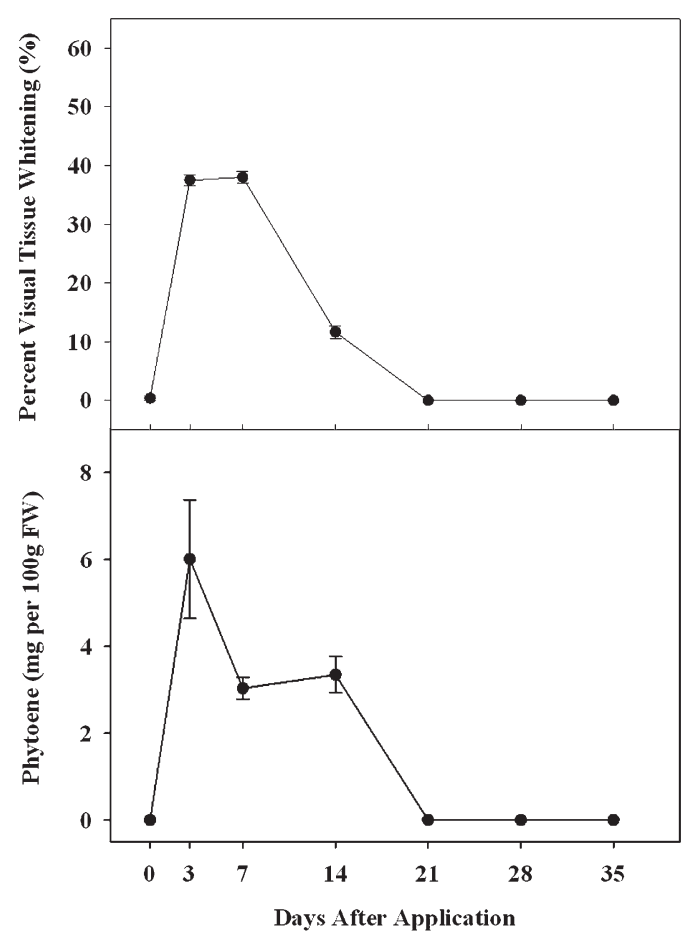

Fig. 1. Leaf blade percent visual whitening (\%) and phytoene concentrations $(\mathrm{mg} / 100 \mathrm{~g}$ fresh weight) in 'Riviera' bermudagrass [Cynodon dactylon (L.) Pers.] treated with mesotrione at $0.28 \mathrm{~kg}$ a.i./ha (•) and sampled at $0,3,7,14,21,28$, and $35 \mathrm{~d}$ after treatment. Means pooled from two experimental runs with error bars indicating sDs. 


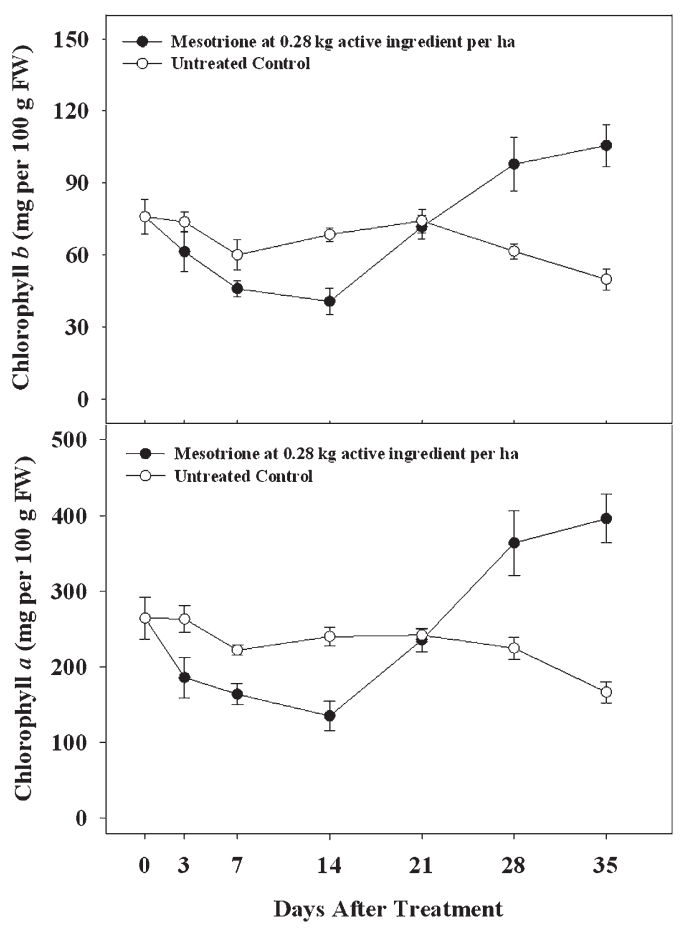

Fig. 2. Leaf blade chlorophyll $a$ and chlorophyll $b$ concentrations ( $\mathrm{mg} / 100 \mathrm{~g}$ fresh weight) in 'Riviera' bermudagrass [Cynodon dactylon (L.) Pers.] treated with mesotrione at $0.28 \mathrm{~kg}$ a.i./ha $(\bullet)$ or untreated control $(\circ)$ and sampled at $0,3,7,14,21,28$, and $35 \mathrm{~d}$ after treatment. Means pooled from two experimental runs with error bars indicating SDS.

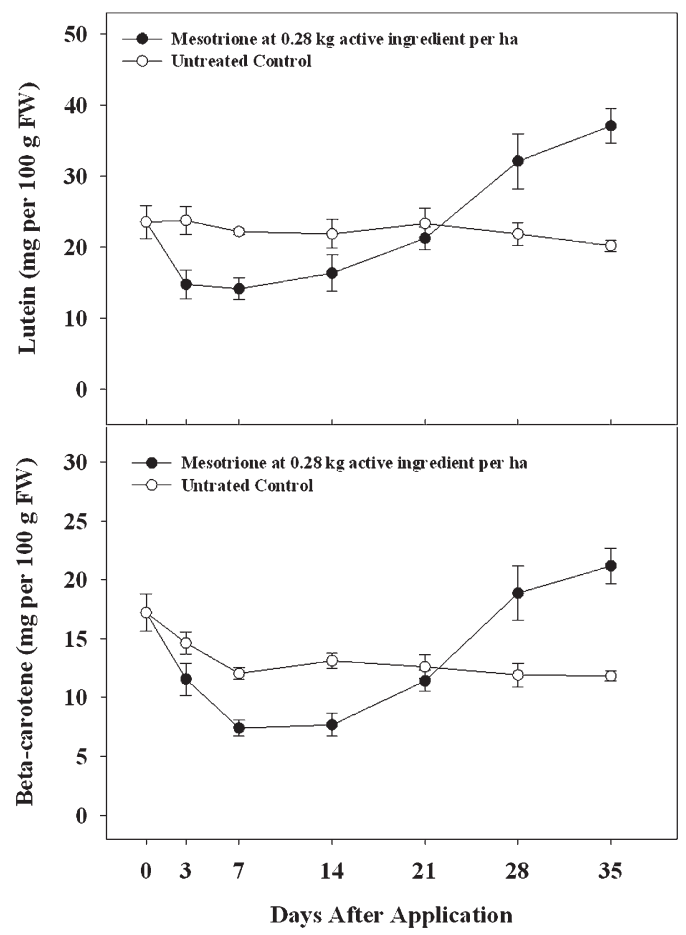

Fig. 3. Leaf blade lutein and $\beta$-carotene $(\mathrm{mg} / 100 \mathrm{~g}$ fresh weight) in 'Riviera' bermudagrass [Cynodon dactylon (L.) Pers.] treated with mesotrione at $0.28 \mathrm{~kg}$ a.i./ha $(\bullet)$ or untreated control $(\mathrm{O})$ and sampled at $0,3,7,14,21,28$, and $35 \mathrm{~d}$ after treatment. Means pooled from two experimental runs with error bars indicating SDS.

specific protein complexes of photosystem (PS) I and PS II (Demmig-Adams et al., 1996). In the PS II complex, $\beta$-carotene is close to the reaction center, whereas lutein is present in several light-harvesting antennae components (Demmig-Adams et al., 1996 Niyogi et al., 1997). Lutein and $\beta$-carotene comprised greater than $70 \%$ of total carotenoids measured in the bermudagrass at 0 DAT. Both lutein and $\beta$-carotene decreased rapidly in mesotrione-treated plants from 0 to 14 DAT and then experienced recovery (Fig. 3 ). Lutein and $\beta$-carotene concentrations in mesotrione-treated plants behaved similarly to Chl $a$ and $\mathrm{Chl} b$, decreasing rapidly by 3 DAT and returning to untreated plant levels by 21 DAT (Fig. 3). By 35 DAT, lutein concentrations in mesotrione-treated plants increased to $37.1 \mathrm{mg} / 100 \mathrm{~g} \mathrm{FW}$, whereas lutein concentrations in untreated plants were only $20.2 \mathrm{mg} /$ 100 g FW (Fig. 3). By 35 DAT, $\beta$-carotene concentrations in mesotrione-treated plants increased to $21.2 \mathrm{mg} / 100 \mathrm{~g} \mathrm{FW}$, whereas $\beta$-carotene concentrations in untreated plants were only $11.8 \mathrm{mg} / 100 \mathrm{~g} \mathrm{FW}$ (Fig. 3).

The xanthophyll cycle pigments (zeaxanthin, antheraxanthin, and violaxanthin) participate as antioxidants in light-harvesting complexes (Demmig-Adams et al., 1996; Niyogi et al., 1997). Zeaxanthin is the carotenoid primarily responsible for preventing photoinhibition by quenching of singlet oxygen and free radicals in chloroplast membranes (Baroli et al., 2003). Zeaxanthin concentrations in bermudagrass tissues did not differ between mesotrione-treated and untreated plants up to 14 DAT (Fig. 4). However, after 14 DAT, there were steady increases in zeaxanthin carotenoids in mesotrione-treated plants. By 35 DAT, zeaxanthin concentrations in mesotrione-treated plants increased to 6.4 $\mathrm{mg} / 100 \mathrm{~g} \mathrm{FW}$, whereas zeaxanthin concentrations in untreated plants were only $3.0 \mathrm{mg} / 100$ g FW (Fig. 4). Violaxanthin concentrations in the bermudagrass tissues showed a sharp decrease in mesotrione-treated plants by 3 DAT (Fig. 4). Violaxanthin continued to be significantly lower in mesotrione-treated plants when compared with untreated plants at 7 , 14,21 , and 28 DAT. Concentrations of violaxanthin recovered to untreated plant levels by $35 \mathrm{DAT}$. The enzymes violaxanthin deepoxidase and zeaxanthin epoxidase mediate conversions within the xanthopyll cycle, and their activity can be influenced by environmental conditions (Demmig-Adams et al., 1996; Niyogi et al., 1997). It is possible that mesotrione-induced photoinhibition may influence violaxanthin de-epoxidase activity, thus increasing the conversion of violaxanthin to the intermediate antheraxanthin and subsequently zeaxanthin. Because of the antioxidant activity attributed to carotenoid pigments, changes to carotenoid concentrations, or ratios, may influence bermudagrass stress tolerance.

Our research outlines three distinct findings. First, although mesotrione initially decreased chlorophyll and carotenoid concentrations in bermudagrass after application, pigments increased beyond untreated levels by the end of the study. We hypothesize that temporary cessation of phytoene desaturase activity resulted in accumulations of phytoene in treated plants. On regreening of leaf tissues, and resurgence of phytoene desaturase activity, a greater flux of phytoene into the biosynthetic pathway resulted in greater accumulations of downstream carotenoids (Kopsell et al., 2009). The exact mechanisms as to these increases are still unclear and warrant further study. Second, temporary 


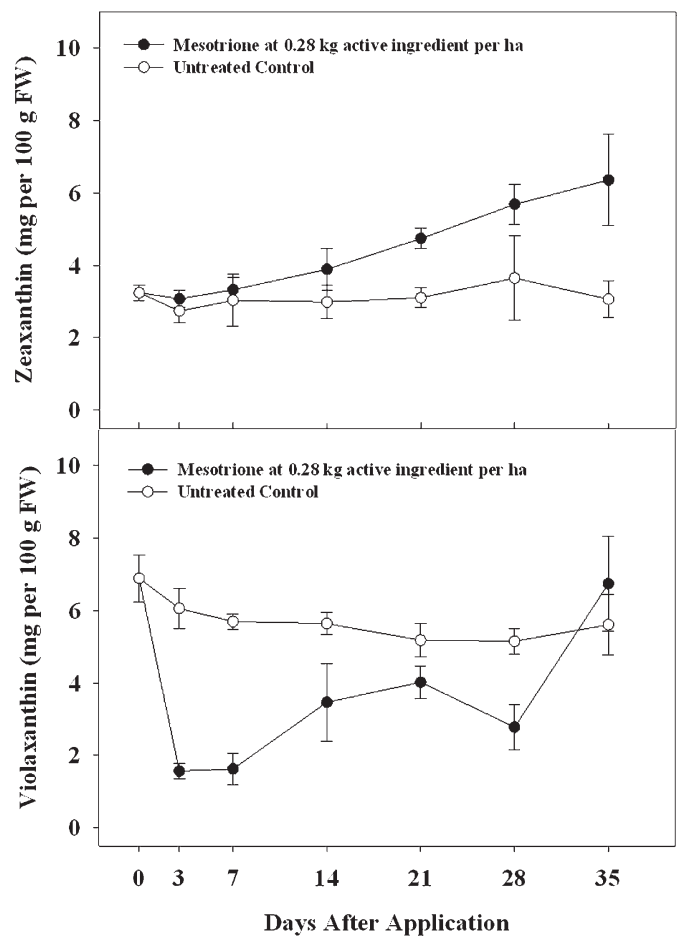

Fig. 4. Leaf blade zeaxanthin and violaxanthin ( $\mathrm{mg} / 100 \mathrm{~g}$ fresh weight) in 'Riviera' bermudagrass [Cynodon dactylon (L.) Pers.] treated with mesotrione at $0.28 \mathrm{~kg}$ a.i./ha $(\bullet)$ or untreated control $(\mathrm{O})$ and sampled at $0,3,7,14,21,28$, and $35 \mathrm{~d}$ after treatment. Means pooled from two experimental runs with error bars indicating SDS.

cessation of phytoene desaturase activity did not result in equivalent decreases in all carotenoid compounds. Third, mesotrione affected xanthophyll cycle functions by causing increases in zeaxanthin concentrations at the apparent sacrifice of violaxanthin carotenoids. Study results demonstrate initial decreases in pigment concentrations induced by mesotrione eventually led to higher concentrations of chlorophylls and carotenoids in bermudagrass leaf tissues at 28 to 35 DAT. As a result of the antioxidant activity of carotenoid pigments, these increases may impact bermudagrass stress tolerance. Future research could be done to determine the residual nature of these affects beyond the tissue collect in the current study (greater than 35 DAT).

\section{Literature Cited}

Anonymous. 2008. Tenacity TM: A herbicide for the selective contact and residual control of weeds in turfgrass for golf courses and sod farms. Syngenta Crop Protection, Inc., Greensboro, NC. CAS No. 104206-82-8. 1 Aug. 2009.
$<$ http://www.syngentaprofessionalproducts.com/ pdf/labels/SCP1267AL11207.pdf>.

Baroli, I., A.D. Do, T. Yamane, and K.K. Niyogi. 2003. Zeaxanthin accumulation in the absence of a function xanthophyll cycle protects Chlamydomonas reinhardtii from photooxidative stress. Plant Cell 15:992-1008.

Bungard, R.A., A.V. Ruban, J.M. Hibberd, M.C Press, P. Horton, and J.D. Scholes. 1999. Unusual carotenoid composition and a new type of xanthophyll cycle in plants. Proc. Natl. Acad. Sci. USA 96:1135-1139.

Croce, R., R. Remelli, C. Varotto, J. Brenton, and R. Bassi. 1999a. The neoxanthin binding site of the major light-harvesting complex (LHCII) from higher plants. FEBS Lett. 456:1-6.

Croce, R., S. Weiss, and R. Bassi. 1999b. Carotenoidbinding sites of the major light-harvesting complex II of higher plants. J. Biol. Chem. 274: 29613-29623.

Demmig-Adams, B., A.M. Gilmore, and W.W. Adams, III. 1996. In vivo function of carotenoids in higher plants. FASEB J. 10:403-412.

Emenhiser, C., N. Simunovic, L.C. Sander, and S.J. Schwartz. 1996. Separation of geometric carotenoid isomers in biological extracts using a polymeric $\mathrm{C}_{30}$ column in reverse-phase liquid chromatography. J. Agr. Food Chem. 44:38873893.

Frank, H.A. and R.J. Cogdell. 1996. Carotenoids in photosynthesis. Photochem. Photobiol. 63:257-264.

Garcia-Plazaola, J.I., A. Hernandez, E. Errasti, and J.M. Becerril. 2002. Occurrence and operation of the lutein epoxide cycle in Quercus species. Funct. Plant Biol. 29:1075-1080.

Kimura, M. and D.B. Rodriguez-Amaya. 1999. Sources of errors in the quantitative analysis of food carotenoids by HPLC. Archivos latinoamericanos de nutricioin 49:58S-66S.

Kopsell, D.A., G.R. Armel, T.C. Mueller, C.E. Sams, D.E. Deyton, J.S. McElroy, and D.E. Kopsell. 2009. Increase in nutritionally important sweet corn kernel carotenoids following mesotrione and atrazine applications. J. Agr. Food Chem. 57:6362-6368.

Kopsell, D.A., T.C. Barickman, C.E. Sams, and J.S. McElroy. 2007. Influence of nitrogen and sulfur on biomass production and carotenoid and glucosinolate concentrations in watercress (Nasturtium officinale R. Br.). J. Agr. Food Chem. 55:10628-10634.

Latowski, D., J. Grzyb, and K. Strzatka. 2004. The xanthophyll cycle-Molecular mechanism and physiological significance. Acta Physiol. Plant. 26:197-212.

Matringe, M., A. Sailland, B. Pelissier, A. Roland, and O. Zink. 2005. p-Hydroxyphenylpyruvate dioxygenase inhibitor-resistant plants. Pest Manag. Sci. 61:269-276.

McCurdy, J.D., J.S. McElroy, G.K. Breeden, and D.A. Kopsell. 2008a. Mesotrione plus prodiamine for smooth crabgrass (Digitaria ischaemum) control in established bermudagrass turf. Weed Technol. 22:275-279.

McCurdy, J.D., J.S. McElroy, D.A. Kopsell, C.E. Sams, and J.C. Sorochan. 2008b. Effects of mesotrione on perennial ryegrass (Lolium perenne L.) carotenoid concentrations under varying environmental conditions. J. Agr. Food Chem. 56:9133-9139.

Mitchell, G., D.W. Bartlett, T.E.M. Fraser, T.R. Hawkes, D.C. Holt, J.K. Townson, and R.A. Wichert. 2001. Mesotrione: A new selective herbicide for use in maize. Pest Manag. Sci. 57: 120-128.

Niyogi, K.K., O. Bjorkman, and A.R. Grossman. 1997. The roles of specific xanthophylls in photoprotection. Proc. Natl. Acad. Sci. USA 94: 14162-14167.

Pallett, K.E., J.P. Little, M. Sheekey, and P. Veerasekaran. 1998. The mode of action of isoxaflutole, I. Physiological effects, metabolism, and selectivity. Pestic. Biochem. Physiol. 62:113-124.

Secor, J. 1994. Inhibition if barnyardgrass 4hydroxyphenylpyruvate dioxygenase by sulcotrione. Plant Physiol. 106:1429-1433.

Willis, J.B., S.D. Askew, and J.S. McElroy. 2007. Improved white clover control with mesotrione by tank-mixing bromoxynil, carfentrazone, and simazine. Weed Technol. 21:739-743. 